\title{
城市郊野公园的观察与思考
}

南昌红土遗址公园设计实践

\section{OBSERVATION AND \\ REFLECTION OF THE \\ COUNTRY PARK \\ - NANCHANG RED EARTH \\ HERITAGE PARK}

\section{1 背景概况}

随着城市化进程的加快，日趋紧凑的生活节奏和不断增大的工作 压力使得城市居民亲近自然、回归乡野的诉求日益强烈。城市郊野公 园在为居民提供近郊休闲空间的同时, 也可发挥保护乡村自然风景资 源、保护生态环境、开展环境教育等作用 ${ }^{[1]}$

本次设计的场地即位于江西省南昌市郊县安义县, 距离南昌市中 心 $36 \mathrm{~km}$ ，占地面积约 $16 \mathrm{hm}^{2}$ (图1)。场地东望梅岭国家森林公园，周 边为安义古村群等旅游景点。随着当地乡村振兴和文旅开发的推进, 这块方圆 $50 \mathrm{~km}$ 内仅存的网纹红土地貌得以被发现并有望打造为一处城 市郊野公园。

网纹红土是长江中下游地区的一种地质地层, 是第四纪冰川期的 冰碛物在湿热气候条件下经淋溶和风化的产物, 其断面特征为不同年 代的红色土层中夹杂着蠕状白斑。因土质粘重板结，降水不易下渗，

孙翀*

水石设计项目总监

\section{*通讯作者}

地址：上海市徐汇区古宜路188号

邮编: 200235

邮箱：evaasun@163.com

摘要

南昌红土遗址公园位于江西省南昌市近郊, 定位为城市郊野公园。场地以成片的网纹红土和 马尾松林为主。根据对场地的资料研读和实地踏 勘, 设计团队发现场地水土流失情况日渐严重, 动植物群落单一, 且受人工影响严重。考虑到场 地本身已具备 “红土” 这一标志性符号, 且造价 受限, 此次设计旨在打造一处低介入、低维护的 城市郊野公园。通过地质科普、自然教育的方式 使人们参与其中，并创造不同的互动体验。在此 过程中，团队尝试从不同维度审视场地，不断梳 理思路、完善设计。从站在宏观视角、跨越时间 维度观察场地历年来的变化更迭, 到通过微观层 面的实地踏勘发现场地特质，建立与场地的对话 与连接, 最终呈现这处与自然和谐共处的城市郊 野公园。

关键词

城市郊野公园; 网纹红土; 观察; 生态修复; 低 介入; 自然体验

编辑 汪默英 翻译 王颖 肖杰

EDITED BY WANG Moying TRANSLATED BY WANG Ying XIAO Jie
SUN Chong

Project Director of SHUISH

\section{ABSTRACT}

Located in the suburb of Nanchang City in Jiangxi Province, the Nanchang Red Earth Heritage Park is positioned as a country park that features vast vermicular red earth and Pinus massoniana forest. The off-site review and on-site exploration suggested that the site was confronting with problems of severer soil erosion, biodiversity loss, and intensive human intervention. Both to preserve the symbolic red earth in the site and to reduce cost due to limited budget, a country park requiring low intervention and maintenance was proposed. The park would also engage citizens with geological and scientific education programs and create diverse interactive experience. The design strategies were optimized through continuous site observation and reflection, both with historical and existing data in a broader sense and individual feeling by on-site exploration. This way of dialogue and connection to the site finally gives birth to a natural country park that stays in harmony with nature.

\section{KEYWORDS}

Country Park: Vermicular Red Earth; Observation Ecological Restoration; Low Intervention; Natural Experience 


$$
\begin{aligned}
& \text { 1. 项目位于南昌市近 } \\
& \text { 郊, 可东望梅岭国家 } \\
& \text { 森林公园。 } \\
& \text { “红色荒漠” 与网纹 } \\
& \text { 红土细节 } \\
& \text { 1. The site is located } \\
& \text { in the suburb of } \\
& \text { Nanchang City, } \\
& \text { neighboring the } \\
& \text { Meiling Mountain } \\
& \text { National Forest Park } \\
& \text { to its east. } \\
& \text { 2. The landscape of } \\
& \text { "red desert" and the } \\
& \text { vermicular red earth }
\end{aligned}
$$

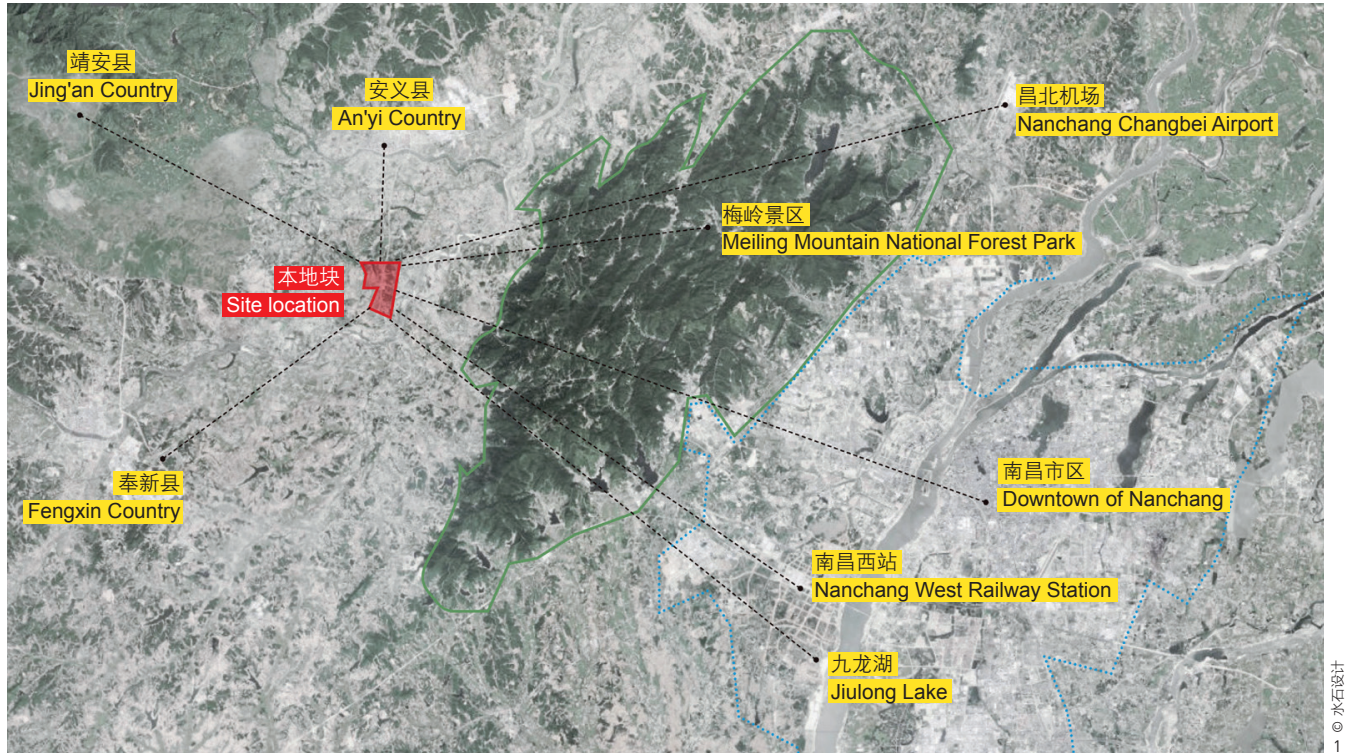

地表径流引起坡面冲刷致使水土流失，常年累月形成了植被稀疏、沟 壑纵横的 “红色荒漠” 景观（图2）。在长期的淋溶作用下，网纹红 土几乎丧失了各种营养元素 (有机质、氮和钾的占比分别仅为 $0.2 \%$ 、 $0.007 \%$ 和 $30 \mathrm{ppm}$ ）。且因其酸性特性，能在网纹红土上生长的植物品种 十分有限。 ${ }^{[2]}$

\section{2 场地初探与实地踏勘}

现状场地中既有大片壮阔的红色荒漠地貌，也有呈斑块状镶嵌于 其间的大片马尾松林（Pinus massoniana）。为了研究场地变化趋势, 设 计团队首先研究了近几年的卫星地图（图3），发现2013 2018年间,
场地内裸露的红土在逐渐减少。一方面是由于植被覆盖率 ( 主要为低 矮灌木）在慢慢增加，大自然在进行缓慢的植被演替。另一方面，则 是由于极端天气、开荒修路等致使场地外围的红土遭到破坏和蚌食。

随后，设计团队利用GIS数据对场地的高程、坡度、水文径流等信 息进行了系统研究。发现场地地势西高东低，高差为 $15 \mathrm{~m}$ 左右。在场地 西侧, 因降水引起的坡面冲刷加剧了红土的流失, 雨水径流逐渐汇集 至地势低洼的东侧区域，在适宜的自然条件的催化作用下，目前场地 东侧生长着马尾松林和草甸。

在完成前期研究后，设计团队进行了实地踏勘，期望通过使用 者观赏和体验场地的视角, 利用五感获取一些更有温度、可共情的感 受。在抵达场地之后，设计团队即被眼前壮阔的红土景观所震撼，认
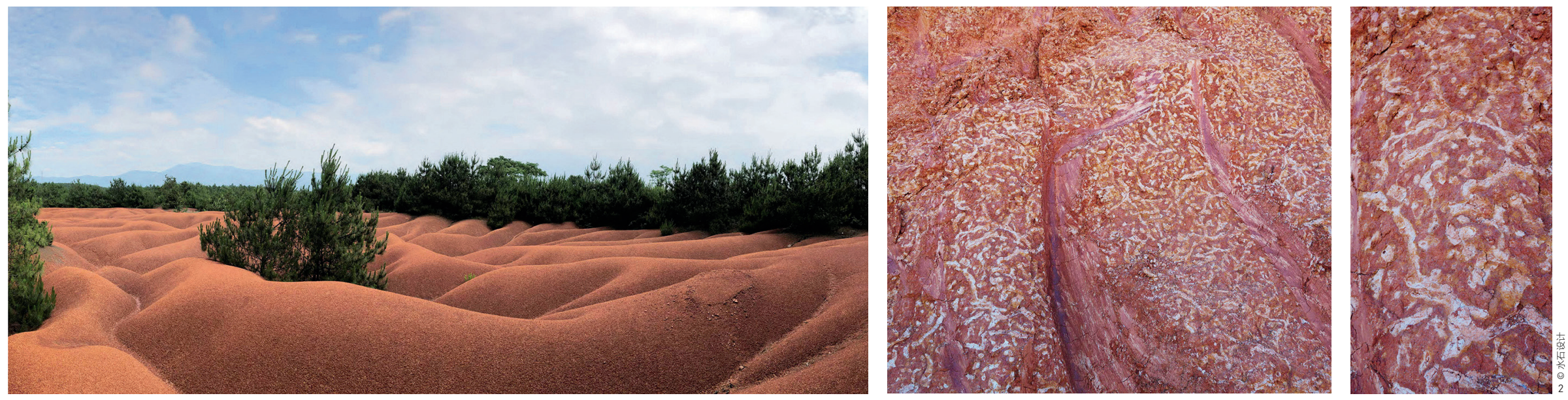


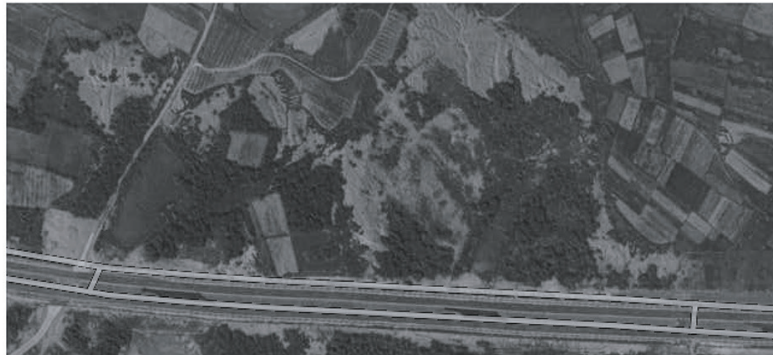

2013年1月

In January, 2013

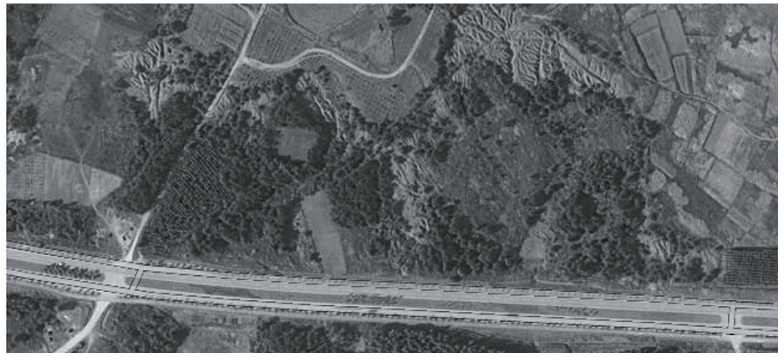

2016年12月

In December, 2016

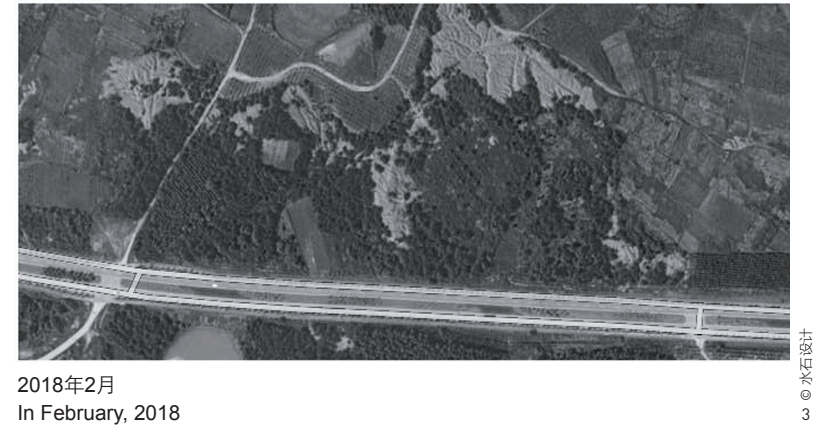

为不应过多地干预场地, 以免喧宾夺主。行走在场地之中, 可以直观 感受到马尾松对视线开合的影响, 并据此初步拟定不同地块的介人程 度一一保留原状、弱干预或适度设计。

通过对场地进行跨越时间维度的研读和细致的实地考察, 设计 团队发现, 场地水土流失情况日渐严峻, 动植物群落单一, 且受人工 影响严重，亟需利用合理的设计策略来对这一独特场地加以保护和修 复。为了发挥场地 “城市郊野公园” 的特性, 亦需思考如何将人带人 场地进行互动。

\section{3 设计思路和策略}

考虑到场地本身已具有足够吸引人的标志性符号, 以及低至 50 元 $/ \mathrm{m}^{2}$ 的造价限制, 此次设计旨在打造一处低介人、低维护的城市郊野公园。 通过地质科普、自然教育的方式使人们参与其中, 去了解这种仿若 “大地之歾” 的自然景观。并基于场地实地踏勘时的感受与发现，创 造不同的互动体验。最终的设计策略 (图4,5) 兼顾生态修复、社会 科普、自然体验、成本效益等多个维度, 提出三个设计目标：首先, 修复场地群落生态环境, 为提升场地动植物多样性创造良好基础; 其 次, 在减少对原生动植物和雨水径流影响的前提下, 创造连续的低介 人慢行栈道系统, 提升使用者参与感; 最后, 营造多样化的空间节 点，丰富在地体验、推广自然科普教育。

\section{1 塑造基础：修复场地生态环境}

生态问题是场地面临的首要问题, 塑造良好的生态基底是整个公 园发展的根基。设计期望依靠生态系统的自我恢复能力, 通过实施适 度的人工辅助措施, 使受损的生态系统逐步恢复, 并不断朝着良性循 环的方向发展 ${ }^{[1]}$ 。最终, 设计团队提出了林相更替 (图6) 和水源涵养 相结合的应对策略（图7）。

南昌本地气候特征为亚热带湿润性季风气候, 当地的稳定植物群 落结构为亚热带常绿阔叶林。而目前场地内是以马尾松为代表的常绿 针叶林, 且乔木品种过于单一, 与稳定的群落结构相差甚远。因此,
通过林相更替策略, 在对现有植被进行保护的基础上, 新增多种乡土 树种, 可以使物种更加丰富, 逐步实现常绿针叶林一常绿针叶阔叶混 交林一常绿阔叶林的自然过渡, 最终停留在稳定的群落状态。

已有研究发现, 植被重建是实现侵蚀退化红壤生态修复的根本措 施之一 ${ }^{[3]}$ 。因此, 设计团队首先引人刺槐（Robinia pseudoacacia）、马 尾松等先锋物种进行斑块化混合种植和土壤改良 (图8)。在不同演替 阶段，植被对土壤质量的恢复改良均有促进作用 ${ }^{[3]}$, 因此经过一段时间 的生长和竞争后, 树种根系和落叶绿肥可以逐步改良红壤的营养与酸 碱度, 最终改善至更适合多数物种生长的条件。在土壤逐渐改良后, 可适当引种一些乡土阔叶类树种, 逐步向亚热带常绿阔叶林群落演 替一一这一过程通常需要数十年的时间。从已有研究可知, 亚热带常
3.2013 2018年间场地卫 星地图变化

4. 采用低介入、低影响的 设计策略, 进行区域生 态修复, 实现带状栈道 串联和点状空间营造。

3. Satellite maps indicating changes of the site from 2013 to 2018

4. Strategies with low intervention and low impact were proposed to realize regional ecological restoration and to link dotted nodes by the linear boardwalk.

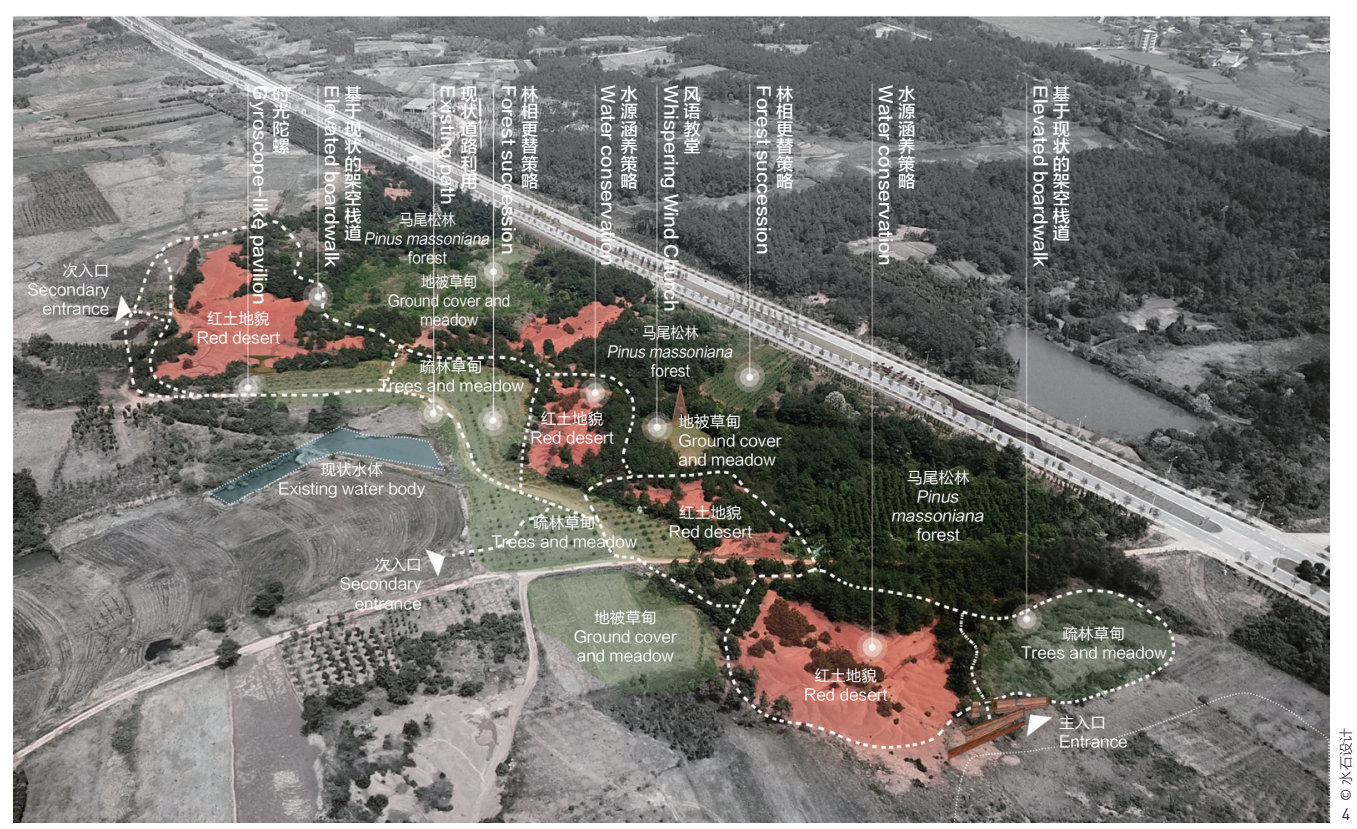




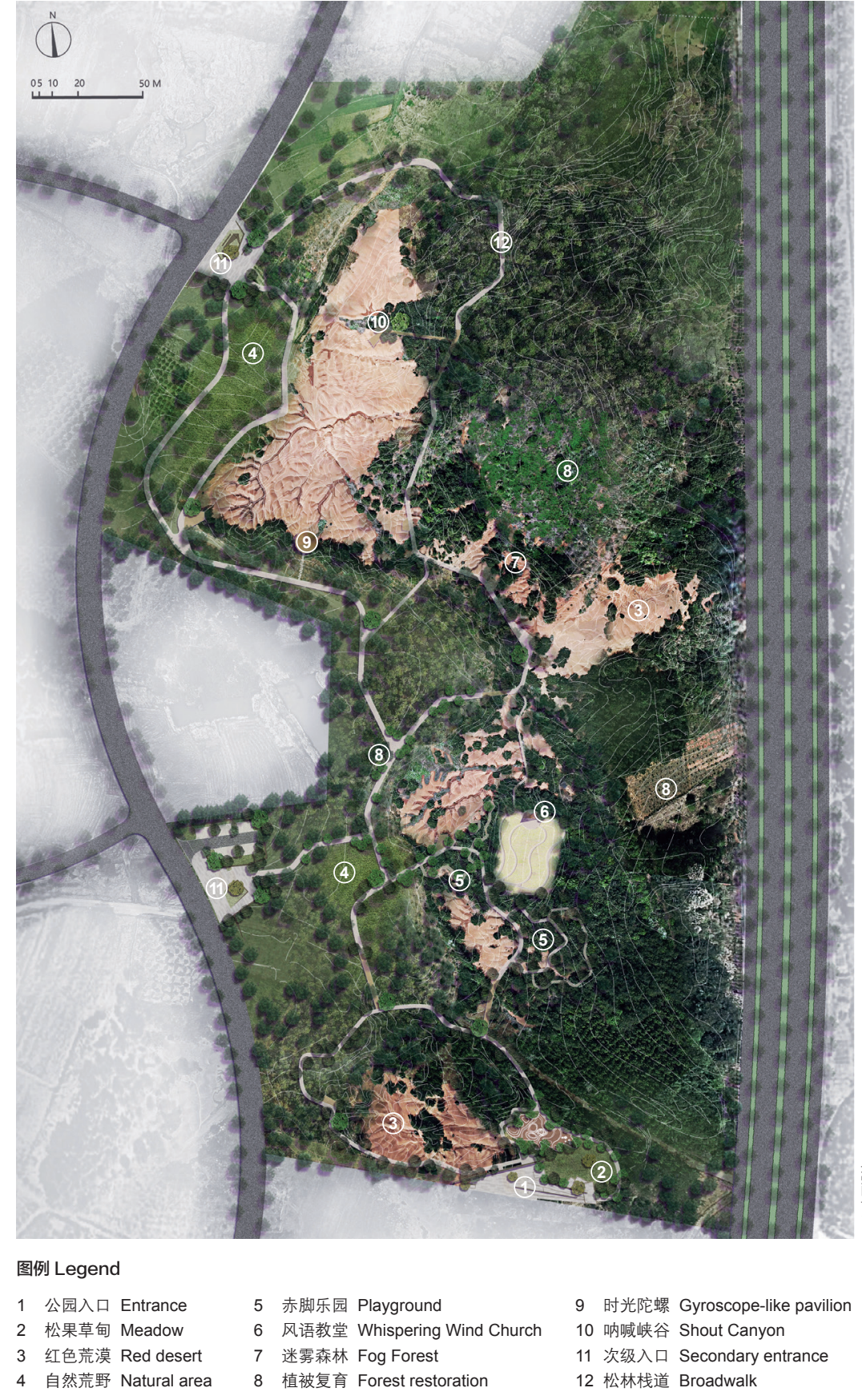

$\begin{array}{lll}\text { 5. 这处占地 } 16 \mathrm{hm}^{2} \text { 的城市 } & \text { 5. } & \text { This } 16 \text {-hectare country } \\ \text { 郊野公园集生态修复、 } & \text { park realizes a balance } \\ \text { 自然体验和科普认知为 } & \text { between ecological } \\ \text { 一体。 } & \text { restoration, natural } \\ & \text { experience, and public } \\ & \text { education. }\end{array}$

绿阔叶林群落乔木层的建群种是壳斗科、樟科和山茶科植物，下层为 杜鹃花科、山茶科和冬青科植物 ${ }^{[4]}$, 因此设计团队也建议从这些科中选 取适宜植物进行配植。

此外，在现有场地地势和坡向现状下，雨季时的水文径流会冲 刷红土, 造成水土流失, 因此水源涵养也是生态修复的重要部分。 设计团队在径流冲沟中种植了喜湿的旱生植物，如芦苇 (Phragmites communis）、千屈菜（Lythrum salicaria）、蒲苇（Cortaderia selloana） 等, 用以降低土壤粘度, 提高土壤渗透性, 截留径流并使其下渗, 恢 复植被并形成水源涵养区，从而减缓雨季径流对红土沟壑地表的直接冲 刷，达到固结土壤、保持水土的目的 ${ }^{[5]}$ 。同时在周边已被村民开屋的经 济林和农田区域, 重新种植乡土优势宿根类和观赏草类植物, 如芒草 (Miscanthus sinensis ) 、蒲苇等, 以涵养水源, 改良土质（图9）。

生态修复带来的生态及美学价值冊庸置疑, 但由于自然的演化过 程较为漫长, 这些价值往往需要假以时日才能逐渐显现。对于一个即 将投入使用的城市郊野公园而言，立竿见影的休闲游憩价值也不容忽 视。因此, 在生态基底修复后, 迎来了下一个问题: 人们要如何与场地 互动? 设计根据不同的场地条件和功能区位, 给出了多元的答案。

\section{2 加强参与: 建立交通廊道体系}

针对红土裸露面积较大的区域, 设计团队在充分尊重现状地貌和 植被的基础上，以最小介人方式引人了交通廊道体系，并明确了三条 道路系统布置原则：一是避免穿过裸露的网纹红土区域；二是尽量避 让现状大乔木点位; 三是尽量利用场地西侧原有的土路基础, 减少不 必要的土方开挖。

团队在此原则基础上进行了多次实地踏勘, 利用GPS定位工具和 $\mathrm{CAD}$ 平面定位反复核验, 确认廊道的最终走向, 并用彩色旗帜在场地中 进行定位放线标注, 指导最终的施工（图10)。为了减少对现状地貌 和植被的破坏，同时避免阻隔场地内的雨水径流，设计最终采用了浅 基础形式的架空栈道（图11）。由于场地条件复杂、空间狭小，为了 避免施工过程中对场地的破坏，施工期间基础开挖和材料运送均依靠 人力而非机械设备完成, 最大程度地保护了场地原貌（图12 14）。

在交通廊道系统内部, 设计团队还选取了空间相对开阔和视野较 好的位置, 设置不同朝向和尺度的观景平台一一或可观赏壮阔的红土 地貌, 或可远眺梅岭山峦。基于场地踏勘时寻得的一处最佳视野, 设 计团队建造了名为 “时光陀螺” 的观景亭 (图15,16)。当人们身处 其中, 望向眼前壮阔的红土景观, 感受沉静的周边环境, 会觉得时光 仿佛静止了一般（图17）。

\section{3 丰富体验：创造多样活动空间}

在场地外围和已经形成了茂密草甸的区域, 设计则希望引人多样 化的活动空间, 加强使用者与场地的互动一一既包括身体层面对场地 的使用，也包括精神层面对场地的感知。空间节点的设计均充分借助 客观的场地条件和主观的实地踏勘体验，希望将设计师们敏锐的观察 
林相更替策略 Forest succession

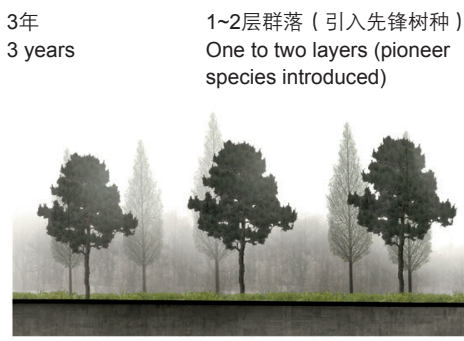

乔木层: 马尾松、刺槐

草本层: 芒其、壳斗科、山茶科阴生幼树 Arbor layer: Pinus massoniana, Robinia pseudoacacia

Herb layer: Dicranopteris dichotoma, Fagaceae, Theaceae (shade sapling) 10 years

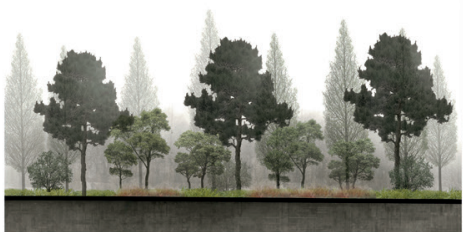

乔木层: 壳斗科、樟科

亚乔木层: 山茶科、木兰科 草本层: 莎草科

Arbor layer: Fagaceae, Lauraceae

Sub-arbor layer: Theaceae, Magnoliaceae Herb layer: Cyperaceae
4层群落 (常绿阔叶林)

30 years Four layers (the evergreen broadleaved forest)

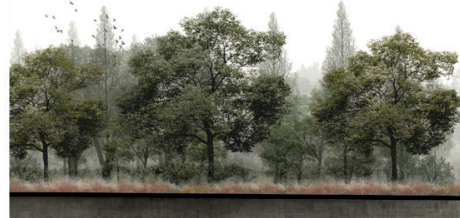

乔木层: 壳斗科、樟科

亚乔木层: 山茶科、木兰科、冬青科 地被层: 杜鹃花科

: 莎草科、禾本科

Arbor layer: Fagaceae, Lauracea

Sub-arbor layer: Theaceae, Magnoliaceae,

Aquifoliaceae

Ground cover layer: Ericaceae

Herb layer: Cyperaceae, Gramineae

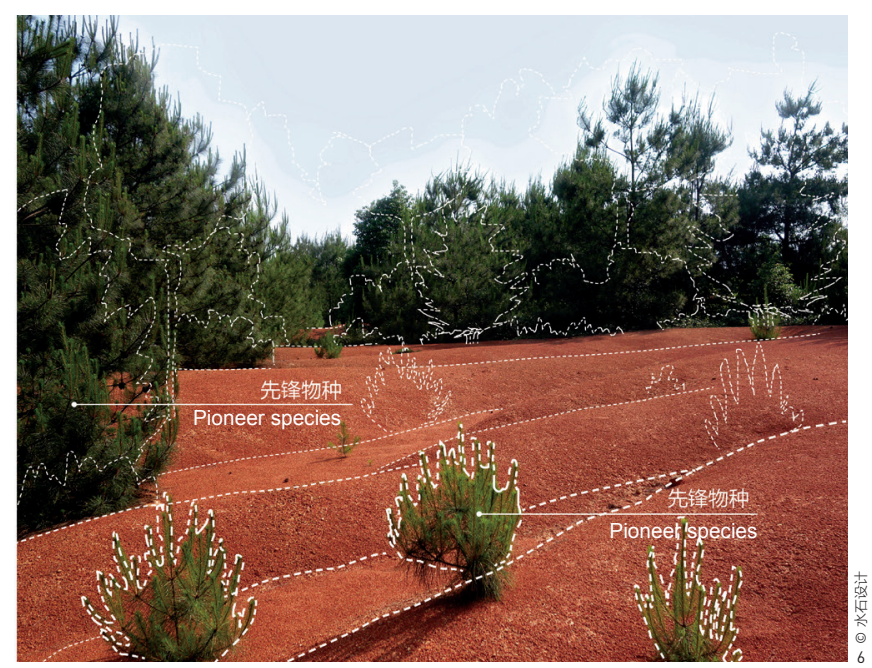

水源涵养策略 Water conservation
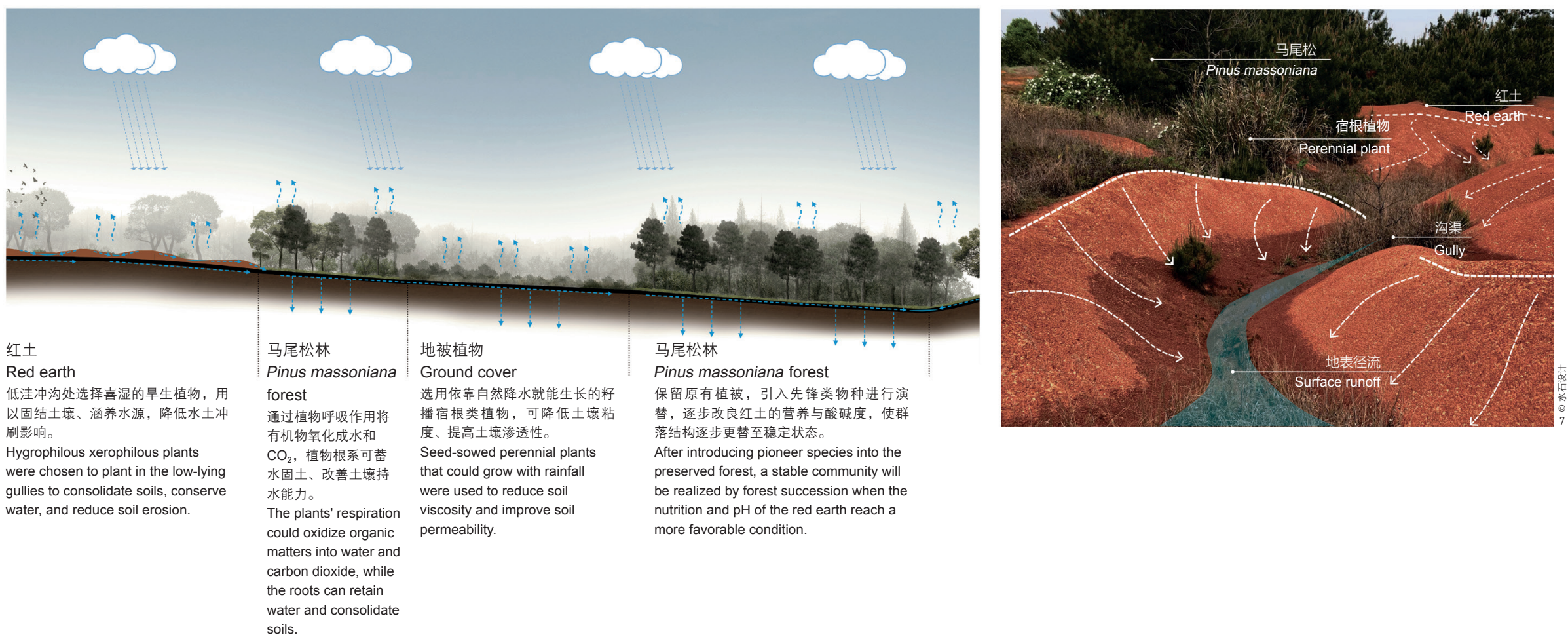

以固结土壤、涵养水源, 降低水土冲

Hygrophilous xerophilous plants

were chosen to plant in the low-lying gullies to consolidate soils, conserve 水能力。 度、提高土壤渗透性。 替, 逐步改良红士的营养与酸碱度，使群 落结构逐步更替至稳定状态。 could oxidize organic

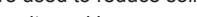

carbon dioxide, whil

water and consolida

soils.

结果呈现给公园使用者, 带领他们观察和感受场地, 创造一种与场地 的连接。

例如, 在公园人口处, 场地内外有 $4 \mathrm{~m}$ 的高差, 这一高差断崖恰好 将网纹红土不同年代的断面层次呈现了出来 (图18)。受到这一地质 断面的启发, 设计确定了直接在现场取土篮土再逐层夯实的方法塑造 人口处的夯土景墙, 以回归传统、回归匠作的方式, 传递出一种拙朴 之美。人们一到人口处, 即可感受到红土遗址公园的主题和气质, 通 过这一前奏融人场地的氛围之中（图19 21）。
此外, 除视觉外其他感官的调动也非常重要。在现场踏勘时, 当设计团队到达一处被大片高大的马尾松林包围的呈矩形的天然草 甸时, 耳畔响起了风吹过松林的沙沙声, 一种强烈的仪式感油然而 生。在这一场所中, 耳畔的声响 (听觉)、风拂过皮肤的凉爽之感 (触 觉）, 超越了场地大部分区域因红土热烈的颜色而占主导的视觉感知。 面对这一偶得的人与自然对话的机会, 设计把这种感受放大, 结合乡土 芒草在场地中设置了一处 “风语教堂” ——在高处悬挂定制风铃的三角 构筑, 最终形成了一处独特的与自然之声对话的空间（图22）。 


\begin{tabular}{|c|c|c|c|}
\hline & \multirow{25}{*}{$\begin{array}{l}\text { 林相更替策略: 常绿 } \\
\text { 针叶林 - 常绿针叶活 } \\
\text { 叶混交林一常绿阔叶 } \\
\text { 林群落更替过渡 } \\
\text { 水源涵养策略: 在径 } \\
\text { 流的冲沟中种植喜湿 } \\
\text { 的旱生植物, 降低土 } \\
\text { 壤粘度, 提高土壤渗 } \\
\text { 琇性, 对径流进行截 } \\
\text { 径流冲刷。 } \\
\text { 公园局部鸟瞰图。近 } \\
\text { 观红土大地, 远望梅 } \\
\text { 岭山峦。 } \\
\text { 乡土的野草荒原 }\end{array}$} & \multirow[t]{8}{*}{6.} & The forest succession \\
\hline & & & strategy: From the \\
\hline & & & evergreen coniferous \\
\hline & & & forest to the evergreen \\
\hline 7. & & & coniferous and broad- \\
\hline & & & leaved forest, and finally \\
\hline & & & to the evergreen broad- \\
\hline & & & leaved forest. \\
\hline & & 7. & The water conservation \\
\hline & & & strategy: Hygrophilous \\
\hline & & & plants planted in \\
\hline 8. & & & the gullies could \\
\hline & & & help reduce soil \\
\hline & & & viscosity, improve soil \\
\hline 9. & & & permeability, intercept \\
\hline & & & surface runoff, and \\
\hline & & & facilitate runoff \\
\hline & & & infiltration, to reduce \\
\hline & & & $\begin{array}{l}\text { runoff erosion in rainy } \\
\text { seasons. }\end{array}$ \\
\hline & & 8. & A bird's view of the \\
\hline & & & park. Visitors can \\
\hline & & & look close at the red \\
\hline & & & earth and overlook the \\
\hline & & & Meiling Mountain. \\
\hline & & 9. & Rural wild meadow \\
\hline
\end{tabular}

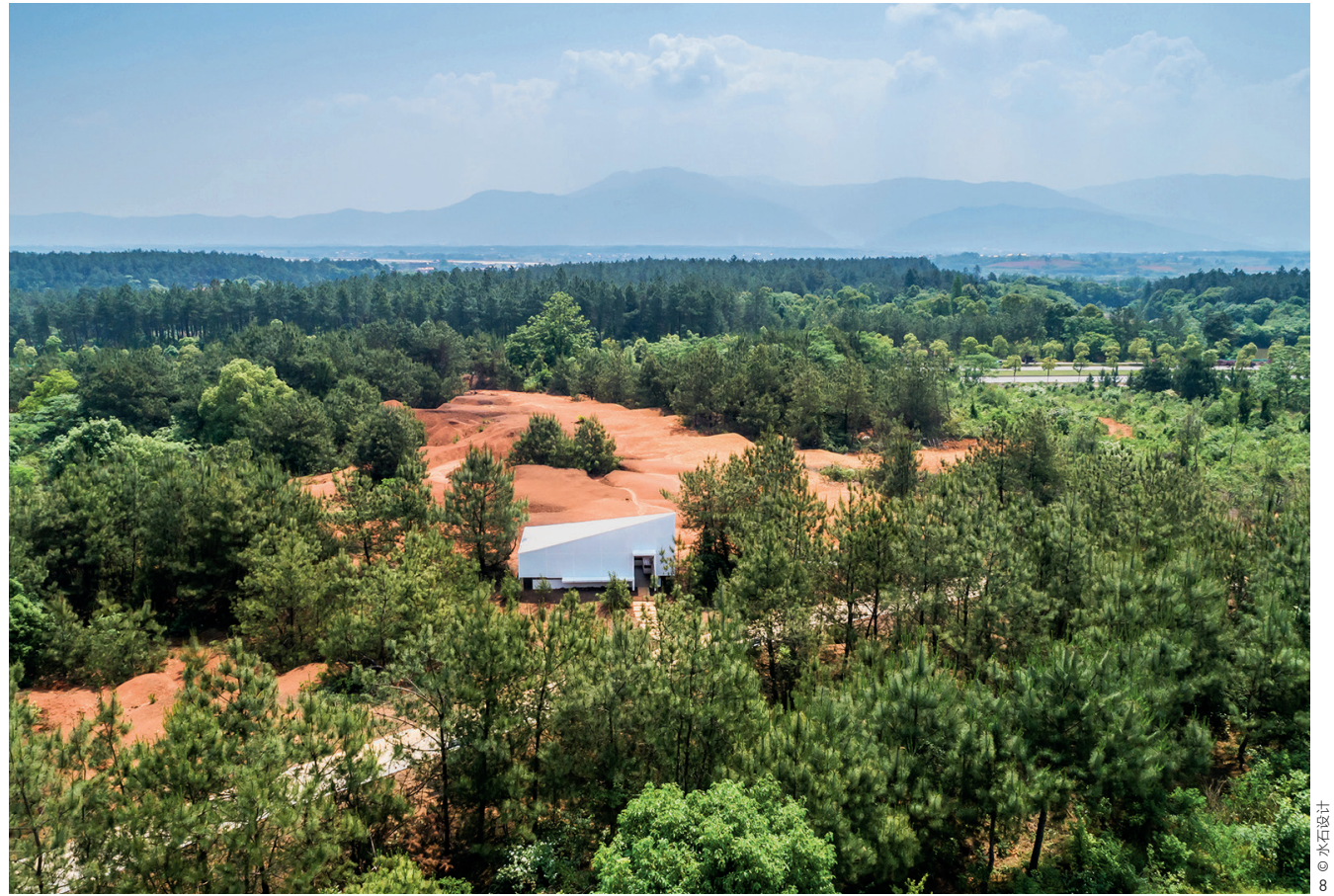

\section{4 讨论与评述}

景观是一门关于大地的学科, 不管是何种类型的设计项目, 都 应从场地人手，从观察切人。但 “看见” 不等于 “看到” ，能否 “看 到” 场地的核心和特质取决于观察的角度，这其中的差别是微妙的。 观察可以是多维度的，既包括从宏观层面跨越时间与认识视角的限制 （例如借助历史/现状卫星图和GIS数据），也包括从微观层面调动感 官进行细致的感受。观察、思考、策略、表达、建造是一个环环相扣 的过程。在这一过程中, 观察与思考通常是呈正比的一一观察角度的 多元决定了思考层面的多维。但表达和建造却并不一定与前二者成正 比。最终的表达和建造方法可能是简单的, 这是因为在多维的观察和 思考后, 发现适度的介人才是最合适的。作为中间环节的 “策略” 则 扮演着媒介和纽带的角色。红土遗址公园看似 “少” 的设计, 却也包 含着 “多” 的思考, 并尽可能地营造出了 “多” 的体验。既尊重了场 地本身的特质，同时又拓展了场地的意义。

设计的结束绝不是观察与思考的终点, 跨越时间维度的观察不仅 要回顾历史，同样也要追踪未来。项目建成后的不断观察、跟踪和记 录, 也能为初始的设计和思考提供验证, 检验场地是否真正按照设想 的轨迹演替发展，为下一次的实践提供数据和佐证。因此从这一角度 上讲，设计还远远没有完成。

设计团队希望从多维观察与思考人手，最终回归情感与自然。用 一种对自然的敬畏之心，回应大地的雕刻时光。LAF
项目信息

项目地址：中国江西省南昌市安义县

项目面积: $16 \mathrm{hm}^{2}$

项目季托：绿地焦团江西事业部

景观设计: 水石设计

首席设计师：孙翀

设计团队：水石设计景观事业二部：祁锋、赵晓东阳、陈佳毅、龙勇、陈宇奇、王文珍

设计时间: 2018年5 7月

施工时间：2018年8月 2019 年5月

所获桨项：2019IFLA亚大地区景观设计专业奖公园与开放空间类木出奖

致谢

在本文撰写过程中, 得到了赵谷风博士的悉心建议, 在此表示感谢。

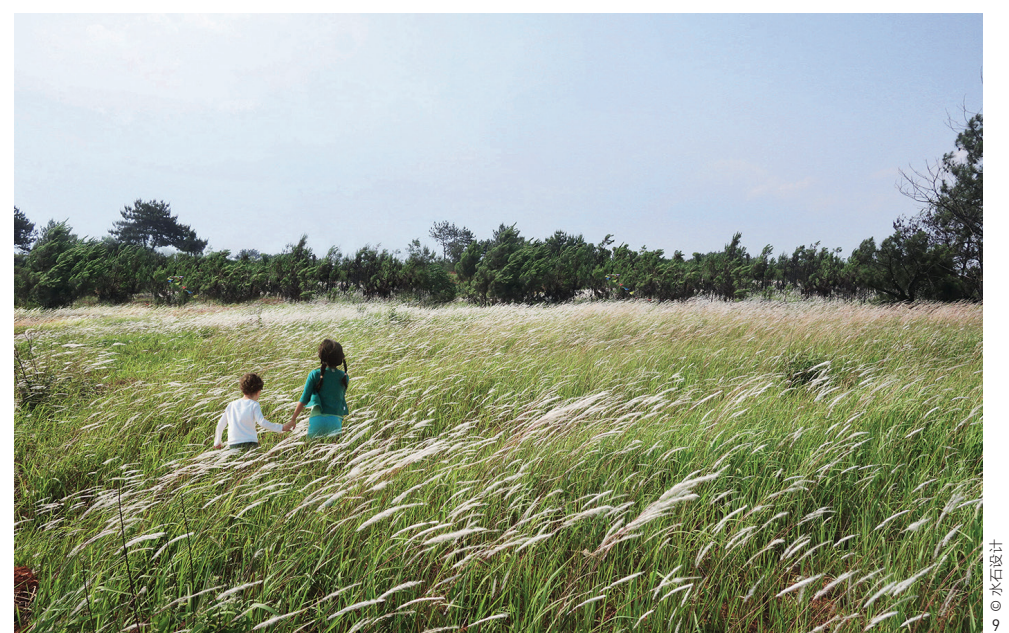




\section{Background}

Urban dwellers are eager to get closer with nature as they are pressed by faster pace of life and growing stress at work under rapid urbanization. Country parks, providing an entertaining option for citizens, could also function to protect the natural resources and ecological environment in rural areas while educating the public ${ }^{[1]}$.

The site of this design is located in Anyi County, a suburb country of Nanchang in Jiangxi Province which is 36 kilometers away from the downtown (Fig. 1). Neighboring the Meiling Mountain National Forest Park to its east, the $16 \mathrm{~km}^{2}$ site is also surrounded by tourist attractions such as ancient villages. Taking full advantage of the rejuvenation of rural areas and the development of local cultural and tourist resources, this site covered by rare vermicular red earth was found and expected to be built into a country park.

Unique to the middle-lower reaches of the Yangtze River in China, the vermicular red earth was made from the moraine of the Glacial Epoch in the Quaternary Period after a longterm leaching and weathering under a humid climate. Layers of red earth formed in different periods and myrmekitic white spots can be found in its section. The thick and hardened soil prevents the surface runoff from infiltration, resulting in soil erosion. After years of water erosion, the landscape of "red desert" that features scarce plants and interlaced ravines comes into being (Fig. 2). Subject to the long-term leaching effect, the vermicular red earth almost loses all the nutrition, retaining only $0.2 \%$ of organic matter, $0.007 \%$ of $\mathrm{N}$, and $30 \mathrm{ppm}$ of $\mathrm{K}$. Worse, few plants could grow here for its being acid. ${ }^{[2]}$

\section{Off-Site Review and On-Site Exploration}

There were both extensive red desert and patches of Pinus massoniana in the site. To study the history of the site, the team reviewed satellite maps over past few years (Fig. 3) and discovered that the bare red earth within the site was diminishing from 2013 to 2018, which were attributed to the gradually increasing vegetation coverage (mainly by short shrubs) and the encroachment on the outside red earth resulted from extreme weather events, farmland reclamation, and road construction.

The following systematical analyses of the site's elevation, gradient, and runoff based on GIS data suggested that it was about 15 meters higher in the west than the east. The rainfall aggravated soil erosion in the west and ran to the east, where the Pinus massoniana forest and the meadow grew thanks to the favorable natural conditions.

On finishing the off-site review, the design team visited the site and examined it from the perspective of ordinary visitors to collect subjective senses. Shocked by the grandeur of the red earth upon arrival, the team decided to conserve the red earth
10. 公园内布置了不同视角 的节点和观景平台, 通 过内部的道路栈道体系

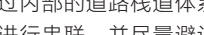
进行妿联, 并尽量避让 现状植被地貌和利用原 始路基

11. 浅基础的架空栈道施工 过程

12. 红土与林间栈道

13. 松林栈道夜景

14. 栈道雪景

10. Nodes and viewing platforms with differen views were arranged and connected by the pedestrian system in the park, avoiding existing vegetation and territory while making use of the original road foundation.

11. The elevated boardwalk with shallow foundation in construction

12. The red earth and the boardwalk in the forest

13. Night scene of the boardwalk in the Pinus massoniana forest

4. The snow-covered boardwalk
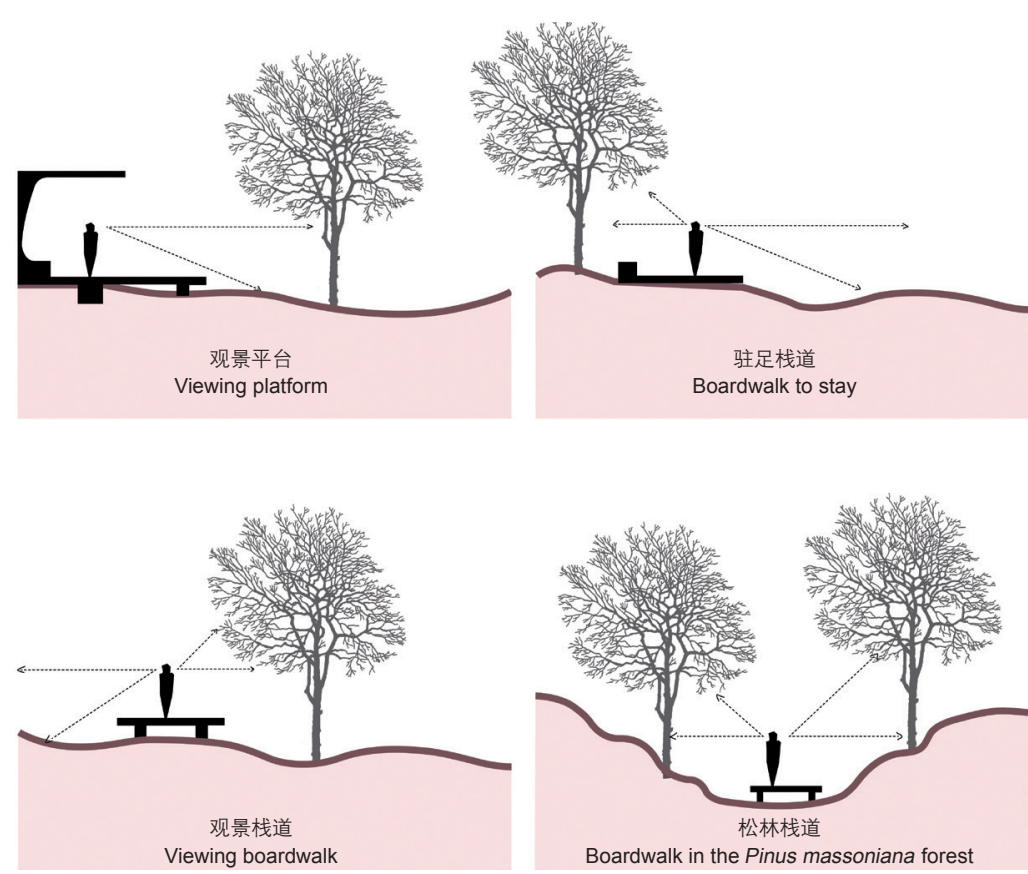

Boardwalk in the Pinus massoniana forest
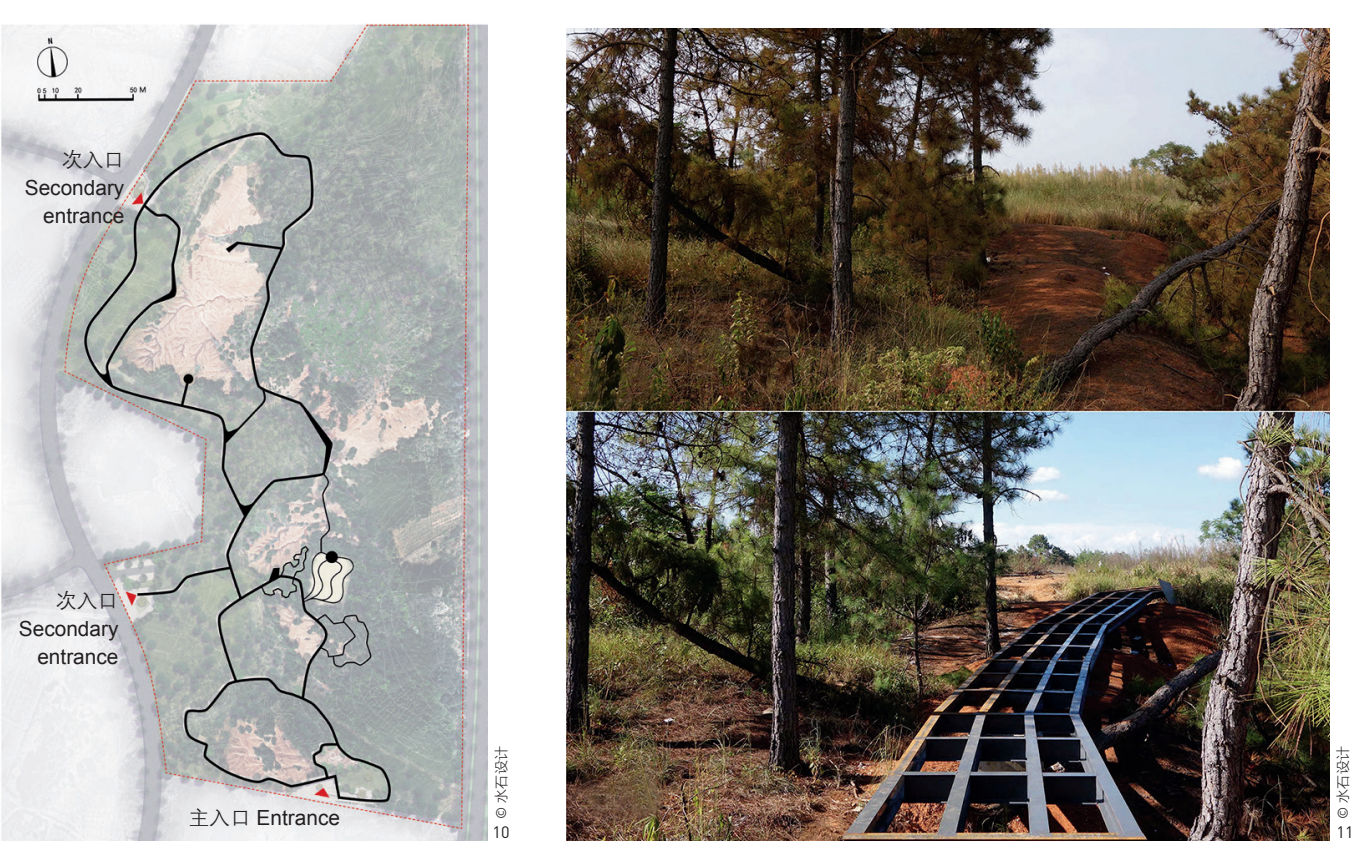
and avoid any aggressive change. The views varied from open to sheltered as the design team moved in the site, according to which different intervention strategies were proposed at different nodes, either to conserve, to intervene minimally, or to design appropriately.

Through careful off-site review across time and on-site exploration, the site was found to be suffering from severer soil erosion, biodiversity loss, and intensive human interventions. It was in urgent need to adopt proper strategies to protect and restore this unique area, while encouraging public engagement to make the site function as a country park.

\section{Design Concepts and Strategies}

Both to preserve the symbolic red earth in the site and to reduce cost due to limited budget, a country park requiring low intervention and maintenance was proposed. The park would also engage citizens with geological and scientific education programs and create diverse interactive experience basing on this peculiar natural landscape. The final proposal (Fig. 4, 5) was aimed first to restore ecosystems for biotic communities and enhance biodiversity; second to create low-intervened pedestrian paths to better engage the public while minimizing impacts on native flora and fauna and the runoff; and third, to create spaces serving diverse purposes, so as to realize a balance between ecological restoration, public education, natural experience, and cost efficiency.

\subsection{Restoring the Ecosystem to Lay the Foundation}

As one of the essential tasks, ecological restoration was given priority to lay the foundation of the park. To realize a naturally resilient ecosystem that could recover gradually with proper human intervention and function well in the future ${ }^{[1]}$, the design team suggested a solution of forest succession (Fig. 6) combined with water conservation (Fig. 7).

The existing site was covered by evergreen coniferous forests - with Pinus massoniana as the dominant species, indicating a loss of plant diversity and discrepancy from the local stable plant community composed of evergreen broadleaved species under the subtropical humid monsoon climate. Regarding this problem, the strategy of forest succession could help preserve existing plants while introducing more native trees in order to enrich the plant species. With a natural succession from the evergreen coniferous forest to the evergreen coniferous and broad-leaved mixed forest, a stable community of the evergreen broad-leaved forest would finally be realized.
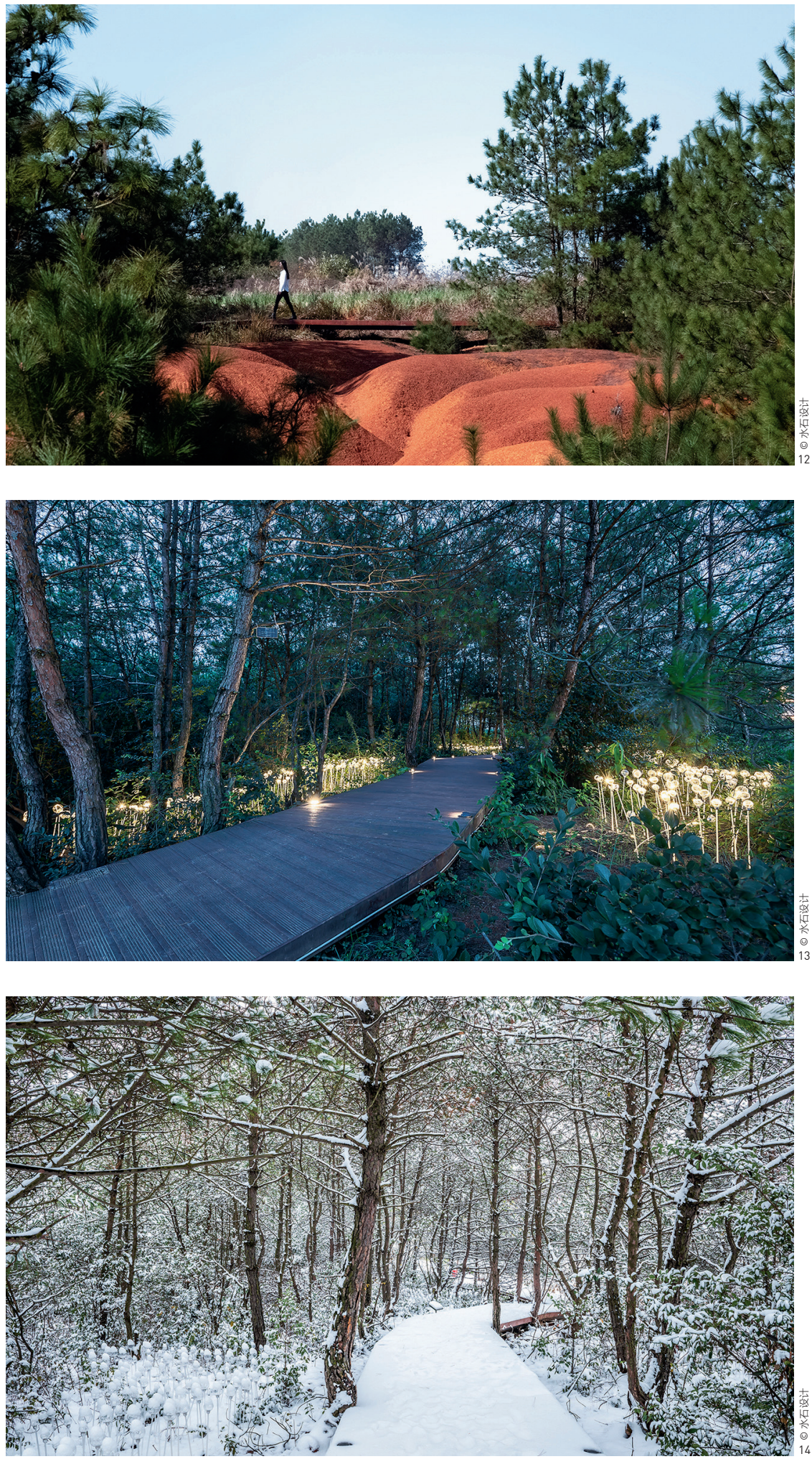


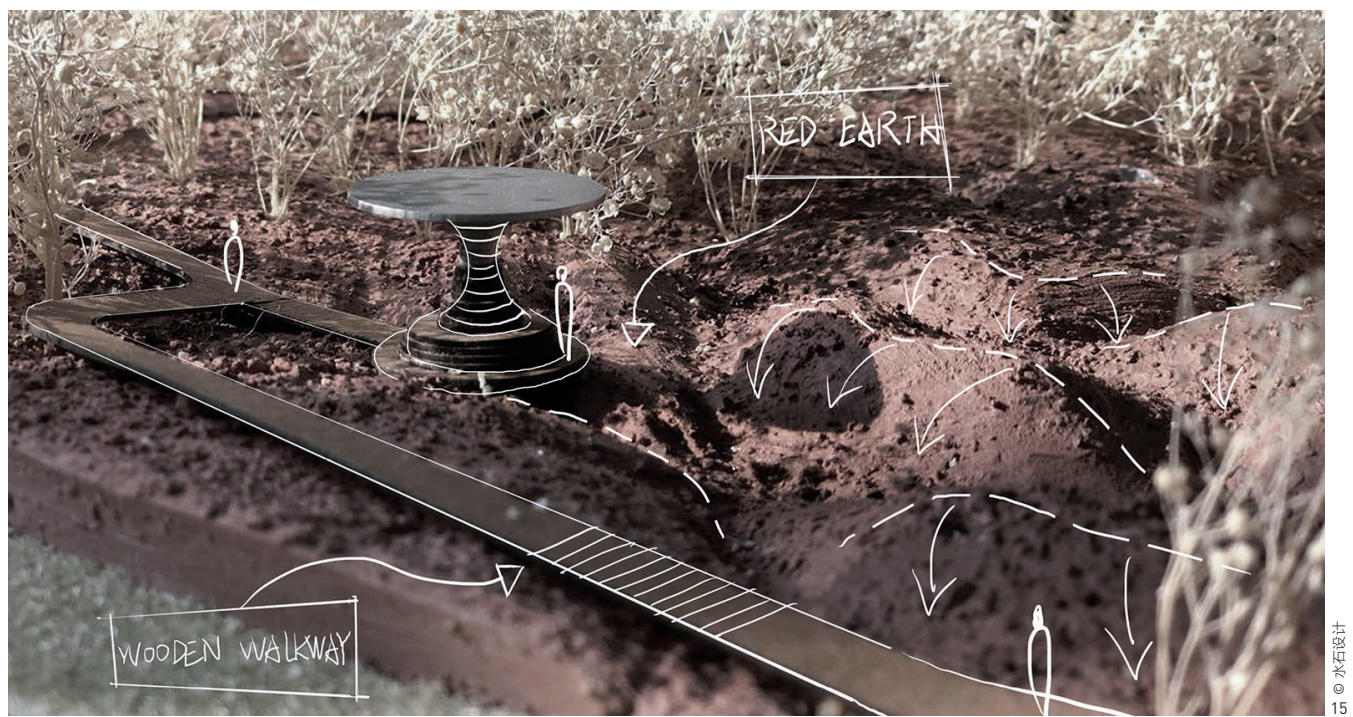

15. 用于研究节点与红土空 间关系的工作模型

15. The model to study the 红土大地与时光陀螺间 的对话

17. 身处时光陀螺之中, 时 间仿佛静止一般。 spatial relationship between different nodes and the red earth

16. The red earth and the gyroscope-like pavilio 17. The gyroscopelike pavilion makes visitors feel lost in the intertwining space and time.

Existing findings suggest that revegetation is core to restore the eroded red earth ${ }^{[3]}$. Thus, the design team employed pioneer species such as Robinia pseudoacacia and Pinus massoniana to mix them into patches and to improve soil conditions (Fig. 8). Vegetation can slowly recover the soil throughout the whole succession process ${ }^{[3]}$, so that over a period both the tree roots and fallen leaves could nourish the red earth and balance its $\mathrm{pH}$ to reach a more favorable condition for most plants to grow. Soil conditions improved and some native broad-leaved trees introduced, the final community of evergreen broad-leaved forest would come into being after decades of succession. Plant arrangement of this community may also learn from findings that the constructive species of tree layer are from Fagaceae, Lauraceae, and Theaceae, while species from

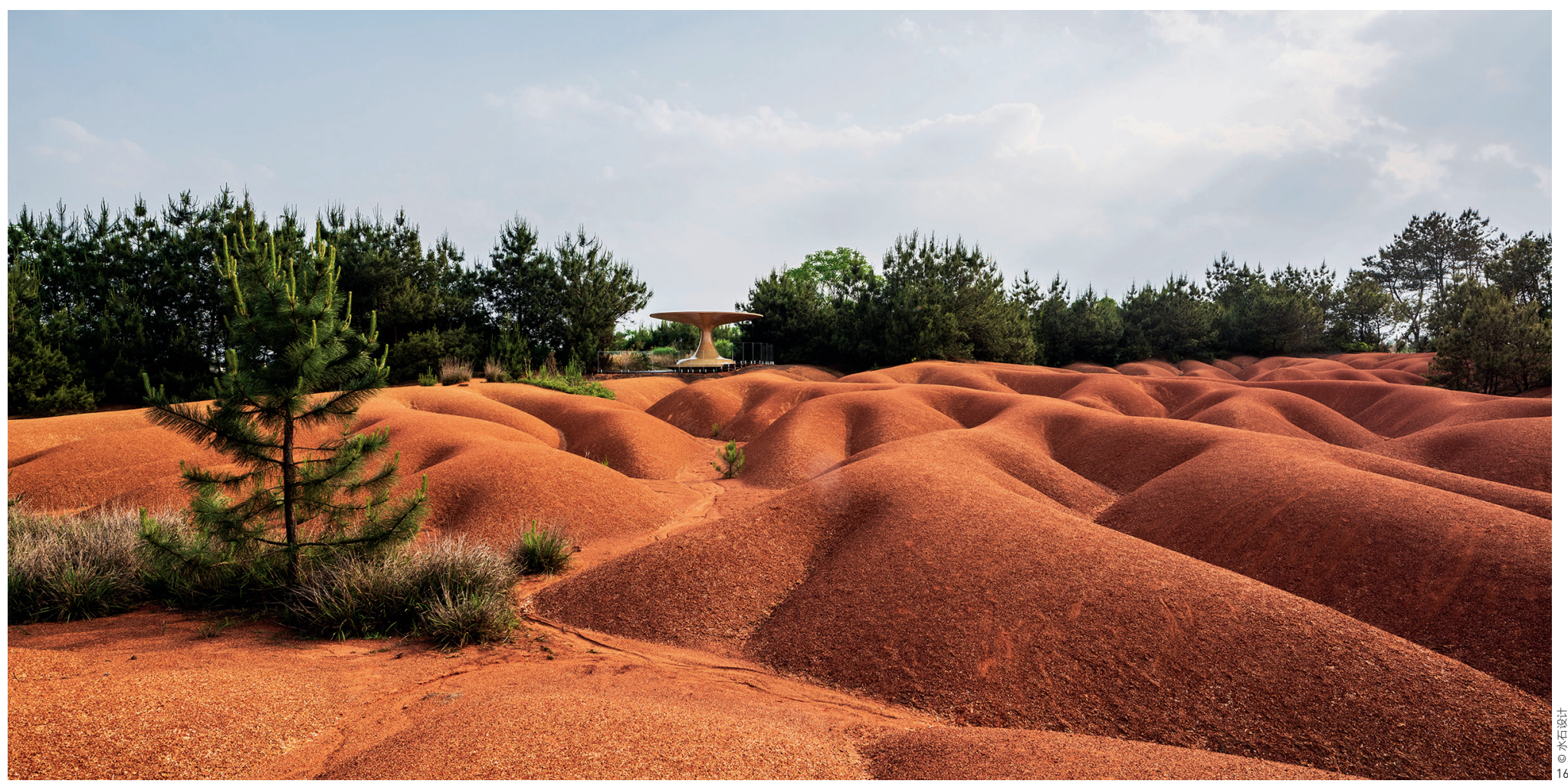




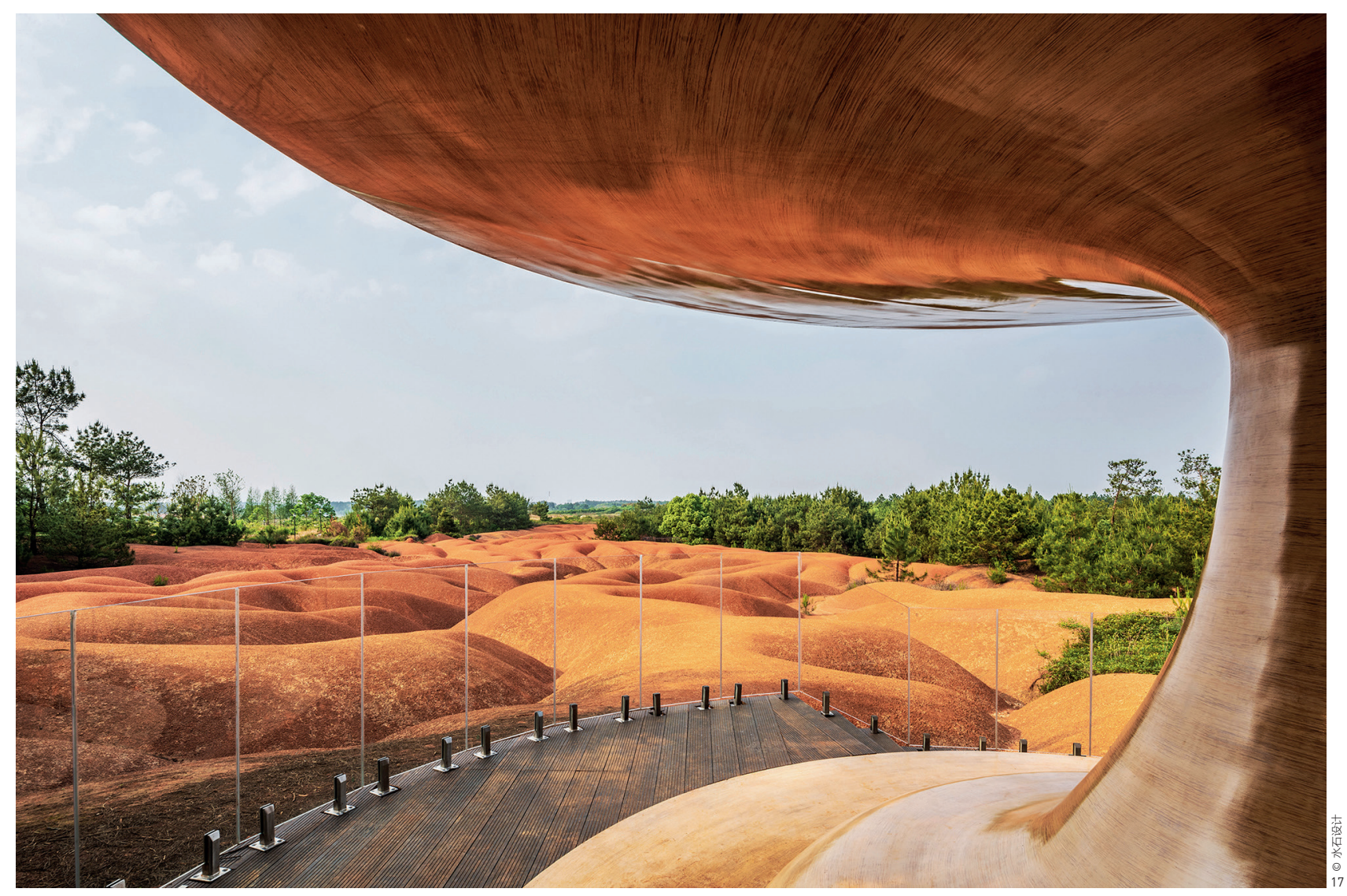

Ericaceae, Theaceae, and Aquifoliaceae would be ideal choices for the lower layers ${ }^{[4]}$.

Water conservation is also significant to ecological restoration. To slow down the runoff and address soil erosion of the site in rainy seasons, hygrophilous xerophytes, such as reeds (Phragmites communis), willow herbs (Lythrum salicaria), and pampas grass (Cortaderia selloana), which could help reduce soil viscosity, improve soil permeability, intercept surface runoff, facilitate runoff infiltration to protect vegetation and conserve water, were designed to plant in the gullies on the red earth ${ }^{[5]}$. Another strategy was to replant native dominant perennial and ornamental grasses, such as the Miscanthus sinensis and pampas grass, in existing economic forests and farmlands to conserve water and improve soil quality (Fig. 9).

Although the ecological and aesthetic values of ecological restoration are undeniable, they cannot be soon perceived as it is time-consuming for nature to evolve. However, for this country park about to put into use, another urgent problem is what should be done to encourage public engagement in realizing the park's significant recreational function, to which the design team responded with multiple choices considering varied site conditions and functional zonings.

\subsection{Establishing Pedestrian System to Enhance Engagement}

For areas with large exposed red earth, the design team introduced a pedestrian system by minimal intervention to fully preserve the existing topography and vegetation. The arrangement of this system should follow three principles of avoiding crossing the exposed red earth area, avoiding existing arbors, and making the most of existing unsurfaced roads in the west side to minimize earthwork.

Under these principles, the pedestrian system's final routes are determined based on on-site exploration and positioning schemes verified by GPS and CAD. To better guide the construction, colored flags were used as location markers (Fig. 10). Finally, an elevated boardwalk with shallow foundation was chosen as it could minimize impacts on the existing topography and vegetation and allow the runoff to flow through (Fig. 11). Instead of utilizing machinery, fundamental excavation and material transportation were conducted manually to protect the 
small-scale site with complicated conditions (Fig. $12 \sim 14$ ).

Along the boardwalk, visitors could enjoy the grandeur of the red earth and overlook the Meiling Mountain through vantage points where viewing platforms in different directions and scales were set (Fig. 15, 16). In the node with a panoramic view, a gyroscope-like pavilion was designed for visitors to stay, feeling immersed in the red earth landscape and lost in the intertwining space and time (Fig. 17).

\subsection{Creating Multi-Functional Spaces to Enrich Experience}

In the periphery of the site and areas with dense meadow, multi-functional spaces were introduced for visitors to interact with the site both physically and mentally. The subjective on-site observation by designers integrated with the objective site condition supported the design of each node, aiming at representing the detailed findings of designers to visitors and creating a link between human and nature.

For instance, inspired by a 4-meter elevation difference at the park entrance, which exactly presented the multi-layered section of the red earth formed in different periods (Fig. 18), the design team raised an analogous landscape wall tamped layer by layer with earth excavated and sieved in the site to apply the traditional craftsmanship and to better bond with the nature. This plain but conspicuous entrance may immediately attract visitors to the park featured with red earth (Fig. $19 \sim 21$ ).

Perceptions other than the visual one are also crucial to on-site exploration. For example, when arriving at a naturally formed rectangular meadow in the site, the design team was impressed by the rustle from the surrounding Pinus massoniana forest and captured the feelings about the grandeur of nature. Here, the auditory and tactile perception of breeze dominated the visual impact by the major red earth area. To represent this special way to dialogue with nature, the designers established a triangular architecture named "Whispering Wind Church" surrounded by Miscanthus sinensis with a customized wind chime hanging on the top (Fig. 22).

\section{Discussion and Reflection}

Landscape Architecture is the discipline on the earth, for which the observation of the site is principal to any project. However, the difference between "seeing" and "observing" should also be noticed, as the latter requires a deeper understanding of the site's core traits through certain perspectives. We may observe both with objective data from historical and existing satellite maps and GIS in a broader sense and individual subjective feeling through different senses by
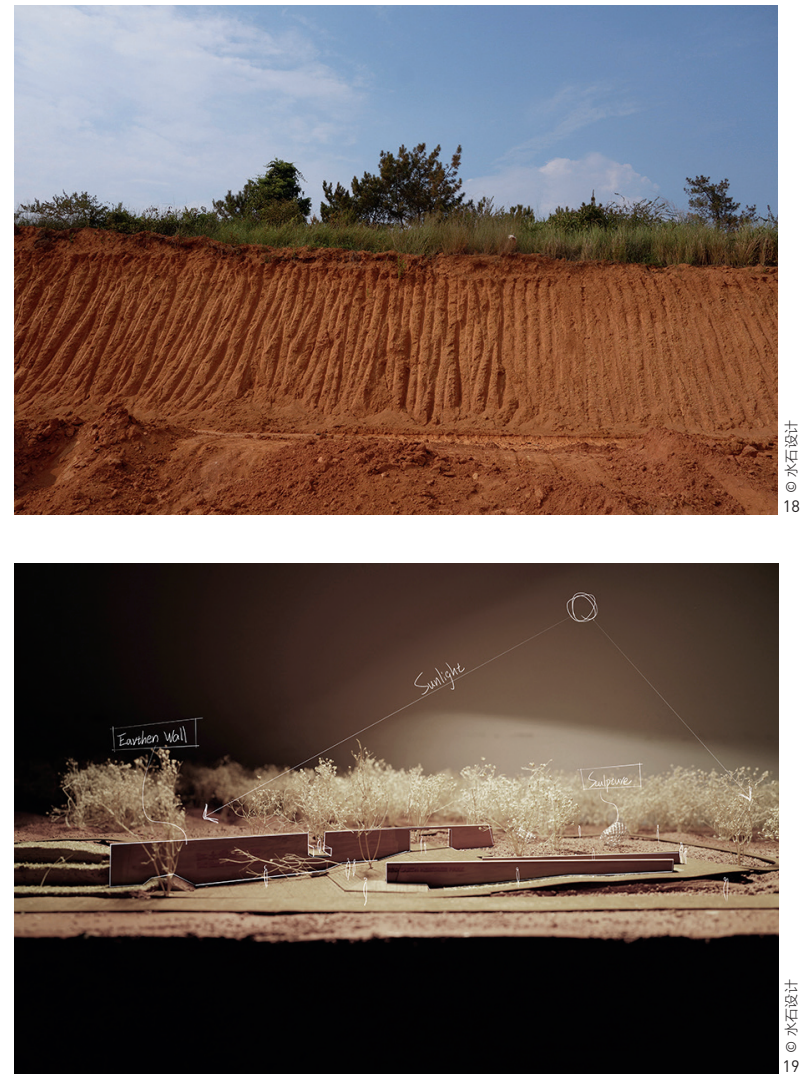

18. 利用公园内外 $4 \mathrm{~m}$ 的高 差, 采用现场取土的爸 土作为 $\lambda$ 口的挡墙, 艻 土作为入口的挡墙, 爸 的地质断面。

19. 研究入口坚向设计和比 例关系的模型

20. 艻土墙与无障碍坡道

21. 公园入口建成效果

18. Making use of the 4-meter elevation 4-meter elevation difference at he park entrance, the retaining wall was tamped with earth excavated in the site, which exactly presented the multilayered section of the red earth.

19. The model to support analyses on the vertical design and proportions between elements of the entrance

20. The rammed-earth landscape wall and the barrier-free ramp

21. The park entrance
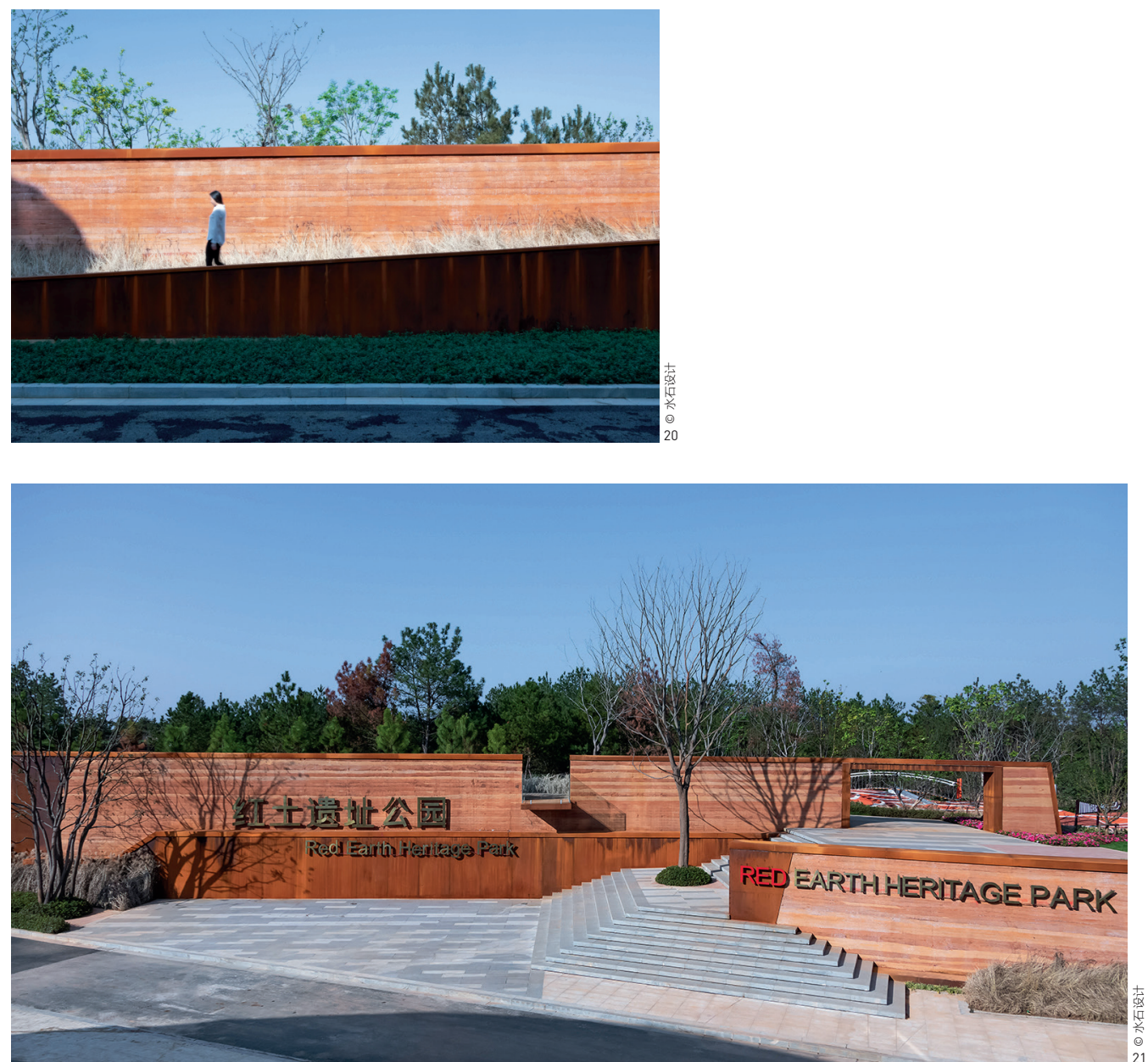
22. 在 “风语教堂”里感受 松涛风语, 实现人与目 然的对话。

22. In the Whispering Wind Church, visitors can dialogue with nature. feeling the rustle from the surrounding Pinus massoniana forest.

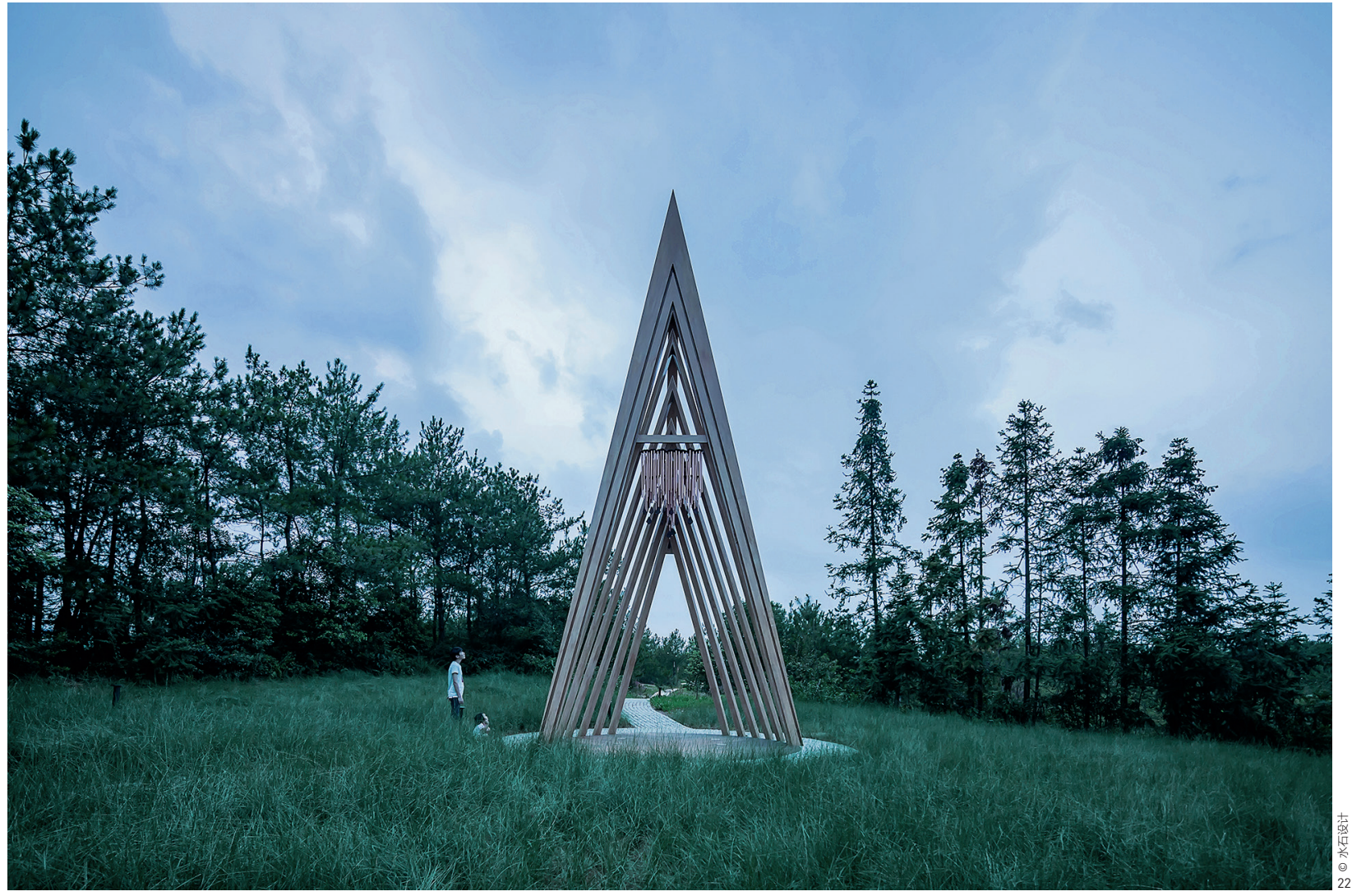

on-site exploration. Basing on the observation and reflection of the site, we could then come up with strategies to make them better represented and realized, during which process we may reflect more thoroughly if with diverse observing perspectives. However, the final construction might be simple as "less may be more." How to make the detailed observation and reflection into the optimum design proposal becomes the core. The Nanchang Red Earth Heritage Park is a good example of this idea - transforming "elaborate" ideas into "little" intervention to preserve the site while providing "abundant" spaces for experience. The proposal finally enhanced the value of the site with respect to its original conditions and features.

The observation and reflection of a site will never end even though the design proposal is finished. A postoccupancy investigation could also provide evidence for proposal verification to help optimize practices in the future. In this view, the design of a site will be ongoing.

Through a multi-dimensional observation and reflection, the design team hopes to celebrate nature with full respect, while responding to its voyage in time. LAF
PROJECT INFORMATION

LOCATION: Anyi County, Nanchang City, Jiangxi Province, China

AREA (SIZE): $16 \mathrm{hm}^{2}$

CLIENT: Greenland Group Jiangxi Division

LANDSCAPE ARCHITECTURE: SHUISHI

CHIEF DESIGNER: Sun Chong

PROJECT TEAM: Qi Feng, Zhao Xiaodongyang, Chen Jiayi, Long Yong, Chen Yuqi, Wang Wenzhen from Department II of Landscape, SHUISH

DESIGN PERIOD: May July, 2018

CONSTRUCTION PERIOD: August, 2018 May, 2019

AWARD: Award of Excellence of Park and Open Space Category. IFLA Asia-Pac Landscape Architecture Awards

ACKNOWLEDGEMENT

The author sincerely acknowledges Dr. Zhao Gufeng for his important suggestions to this article.

\section{REFERENCES}

[1] Zhuang, W., \& Duan, Y. (2019). Ecological Restoration and Reconstruction of Plant Diversity in Country Parks - A Case Study of Shanghai Binjiang Forest Park. Landscape Architecture, 26(1), 4246. doi:10.14085/j.fjyl.2019.01.0042.05

[2] Zhu, J. (1988). Genesis and Research Significance of the Plinthitic Horizon. Geographical Research, $7(4), 42-46$

[3] Wang, X. (2004). Study on soil biological quality changes during secondary succession of vegetation on severely eroded red soil. The Tenth National Congress of Soil Science Society of China and Fifth Cross-Strait Soil and Fertilizer Academic Exchange Seminar Proceedings ISpecial Subject Soil Science about Agricultural and Environmental Health) (p. 2), Shenyang.

[4] Gao, Y., Yang, J., Wu, L., \& Mo, Y. (2012). Application of Ecology Principle in the Plant Disposition. Heilongjiang Agricultural Science, (6), 90-92. doi:10.3969/j.issn.1002-2767.2012.06.032

[5] Zuo, C. (2007). Characteristics and Development Trend of the Soil Conservation Technology j.issn. 1002-2651.2007.01.001 